\title{
Drivers of the Successful Green Manufacturing Outsourcing Decisions in U. S Companies
}

\author{
Syed A. Rehman Khan ${ }^{1}$, Zhang $\mathrm{Yu}^{2}$, Chen $\mathrm{Xi}^{3}$ \\ ${ }^{1}$ School of Economics and Management, Chang'an University, Xi'an, China \\ ${ }^{2}$ School of Printing and Packaging, Xi'an University of Technology, Xi'an, China \\ ${ }^{3}$ School of Economics and Management, Beijing Jiaotong University, Beijing, China
}

Email address:

Sarehman_cscp@yahoo.com (S. A. R. Khan), 2646592586@qq.com (Zhang Yu),m18392061877@163.com (Chen Xi)

\section{To cite this article:}

Syed A. Rehman Khan, Zhang Yu, Chen Xi. Drivers of the Successful Green Manufacturing Outsourcing Decisions in U. S Companies Reinforced Epoxy Composites. Advances in Applied Sciences. Vol. 2, No. 5, 2017, pp. 75-79. doi: 10.11648/j.aas.20170205.14

Received: February 14, 2017; Accepted: March 8, 2017; Published: October 23, 2017

\begin{abstract}
This study will help to understanding the success factors involved in manufacturing outsourcing decisions. In traditional way companies was thinking about outsourcing is only for cost cutting and reduce to the headcounts, but in today's world this trend is changing, and many companies are also using outsourcing for their core competency not only for cost cutting but for flexibility, make free to internal resources for other purposes, available cash and capital for R\&D (research and development). Many companies (manufacturing) are going towards outsourcing their core competency and now companies believe on continuous improvement and facilitation to the customers and make them satisfied and delighted. In the research results most important factor is "supplier competency and reliability" in manufacturing outsourcing decision. Now companies are going towards strategic outsourcing and companies have understood which product they can make in-house or which products they can make by outsourcing in more better way, there are not many successful examples of Dell Corporation, IBM whose are using outsourcing as an strategic. Effective manufacturing outsourcing strategies are not just implemented but should be shaped and mold for particular business and with the competitive need of particular business.
\end{abstract}

Keywords: Supply Chain Management, Drivers, Green Manufacturing, Information Technology

\section{Introduction}

Outsourcing Decision in the manufacturing industry is very hot topic from last few decades. And companies' management tries to find out the way of leveraging capabilities internal and external both. In 1996 Expenditure of outsourcing in U. S was more than $\$ 100$ Billion Ehie, I. C; (2001). Manufacturing accounts is almost 2/3 (two-third) of all outsourcing. Manufacturing account of durable and nondurable goods was $39 \%$ and $25 \%$ respectively out of all outsourcing activities Dun and Bradstreet, (1997). According to the Ehie, I. C, (2001) Electronics manufacturer spent almost $\$ 627$ billion to produce their product by outsourcing which was $13 \%$ approximately of all outsourcing activities. Now outsourcing in manufacturing industry play a vital role, but company first should identify and categorize to the all activities: which activities should be made by in-house and which activities should be outsource to gain fruitful benefits
Collins, R. S \& Bechler, K. A (1998). The purpose of manufacturing outsourcing is to give particular manufacturing activities to third-party, and avoid from unnecessary investment in-house manufacturing Venkatesan, R. (1992). During the 1980s when outsourcing was growing, many companies outsourced their activities and many companies have shifted their manufacturing facilities in China for gaining vast benefits and china become "The world's \#01 Factory". According to the Cantoria, S. C (2011) only 5\% American graduate students earned engineering related degrees in 2001 and almost $46 \%$ were Chinese. As per the estimation 20\% were Indian and Chinese students in total foreign students enrolled in U. S during 2001 and majority Indian and Chinese students were studying engineering and manufacturing related degrees. Usually companies outsourced manufacturing activities when they think, Supplier have a distinct competitive advantage, outsourced to the non-critical activities and be more focus over company's core competitive edge. According to the 
Casale, F. J., (1998) many business consultants claim $20 \%$ to $40 \%$ gain because of outsourcing, but in reality gain is less than $10 \%$ few companies are very good and successful with their outsource decision and other have doubtful. Dupont, has claimed that because of outsourcing few chemical manufacturing, gave them chance to develop competitive edge Dornier, P. et al, (1999) Dell Corporation is also using manufacturing outsourcing to strong their competitive position in the market. IBM has used manufacturing outsourcing to a smaller degree, generating only $\$ 3.50$ for each and every dollar investment Collins, R. S \& Bechler, K. A, (1998) and Ehie, I. C; (2001). Many fruitful benefits can be achieved by manufacturing outsourcing, but still many companies do not know and still those benefits are hidden from the management of manufacturing companies, whose already has been implemented "manufacturing outsourcing decision". To achieving the full benefits of outsourcing strategic fit is very crucial between company and supplier, as well company should find the right supplier who has that skills and capabilities which company need for reducing the cost and increasing total value.

It is little difficult to say when first time word "outsourcing" used, but in last few decades the outsourcing used commonly, and companies started outsourcing many activities handover to suppliers. And focus towards core competencies, traditionally major reason of outsourcing was "cost reduction". But now many companies are using outsourcing, but not only for reduction in cost. Foreign and domestic contracts are included in Outsourcing. According to the (Mullin, 1996) formally outsourcing was not defined as a business strategy until 1989. Many companies were doing outsource their functions when they have no competency (in-house) and which was not important and critical. A process of determining what should be outsourced and which function should be outsourced is called "Outsourcing strategy". A successful outsourcing implementation required strategic fit between company and suppliers as well company should know the answer of the following questions; Objective of outsourcing, outsourcing relationship with corporate strategy, which processes should be outsourced and why, duration (expected) of the outsourcing, risk involved in outsourcing. Ehie, I. C; (2001) usually outsourcing relationships failed because companies consider outsourcing as a short term and tactical decision.

This study will identify leading drivers and success factors which can contribute in successful implementation of manufacturing outsourcing decision. Many companies think about outsourcing is only for cost cutting; outsourcing is a tactical decision; and does not need strong relationship building with their suppliers and outsourcing cannot be for core competency products. According to the Tarsh, S. (1998) in real case the world successful outsourcing companies have very good and strong relationship with suppliers.

\section{General Advantages of Outsourcing}

In the outsourcing, there are many distinctive advantages and still many fruitful advantages in the "manufacturing outsourcing" are hidden. The general advantages of the outsourcing including reducing in capital investment, reducing the cost via (supplier) economies of scale, changing to the fixed expense in to variable, more focus towards core competencies, specialized equipment and skilled labor Quinn, J. B and Hilmer, F. G (1994). According to the Handfield, R. (2006) companies do outsourcing to gain access towards capabilities of world class, control operating cost and reduce, internal resources are free for other purposes, in-houses resources are limited or unavailable, share to the risk, improve host company focus, in earlier decades outsourcing was using only for cost reduction and headcount reduction, but in today's world drivers of outsourcing are becoming more strategic. As per the Narayanan, (2010) organizations expect from the outsourcing the following benefits; increase customer satisfaction, relocation of in-house resources towards core activities, access to international markets and best practices, staffing flexibility, minimizing the operating cost, and more funds are available for investment in R\&D (research and development) and other projects, outsourcing provide opportunity of sharing risk with other organizations, improved quality and cycle times.

\section{Strategic Outsourcing Frameworks}

For analyzing manufacturing outsourcing decision, many frameworks have been proposed. The bottom line of those frameworks was, organizations should utilize their resources and be focused towards those activities in which they can provide competitive edge. Which activities are not critical and core those activities should be outsourced to those suppliers whose have capabilities and skills to fulfill those activities effectively and efficiently. According to the Quinn and Hilmer, (1994) manufacturing outsourcing decisions affected by two drivers: first is business risk -strategic vulnerability means a particular firm has control on the market of supplier \& potential for competitive edge indicates a position has taken by firm that allow them to receive and maintain competitive advantage. Those activities which are not very critical, competitive edge and also vulnerability is low from supplier side, companies should outsourced to these activities. And which activities has high vulnerability (business risk) from supplier side and also has high competitive edge, these activities should be in-house. If both (business risk and competitive edge) are high on that time organizations need high level of control, ultimately degree of flexibility will be reduces. By developing strategic alliance with supplier vulnerability can be minimize and also can improve right control yet leave room for elasticity (flexibility) in demand. According to the Dormier et al. (1999) his framework model has two dimension; Strategic value and criticality of the part for final assembly. 


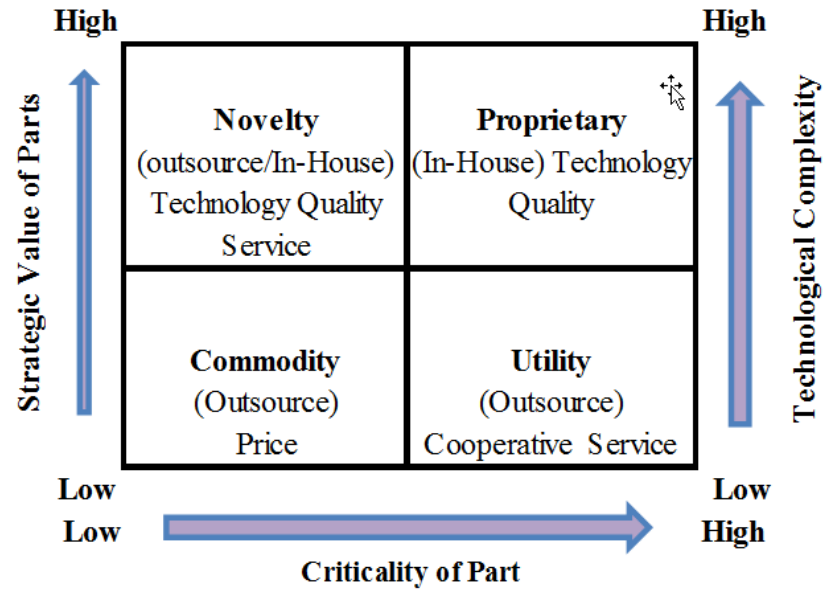

Figure 1. Strategic Value \& Criticality Matrix (Dornier et al. 1999).

The parts strategic value reflects the part's capability to exercise sole superiority in the market. Some major strategic value's indicators are complexity of technology, proprietary nature of technology and in the PLC (product life cycle) the position of the parts matured vs. emerging products. The part (criticality) denotes its contribution in the product's functional performance. Major indicators include the indispensability of the part to the finished goods. As per this model Parts should be classify in four categories, proprietary, commodity, utility and novelty. Propriety parts which must be produced in house and these are core parts and core competency of the organization. For example engine of the car (Honda automobile) and cannon camera imaging device (digital). Novelty parts are those in which technological complexity is high but not very important in functioning of the product like air bags (in automobile). Utility parts are critical but based on readily available technology like cap of radiator (automobile). And commodity products have minimum role in the functioning of the products and involve low technology. Generally two categories are considered core competence area; one is proprietary and second is novelty. Remaining two categories are considered in non-core.

In above discussed both frameworks of manufacturing outsourcing decisions, capabilities of firms and potential in market are considered during decision regarding manufacturing outsourcing. As well organizations should find to outsource activities which have few or less competitive edge. In scenario of technology provides important competitive edge, and is not still matured then firms should find to keep the technology in house. Because off this can be core competence in the future. In simple way, those items which fall in the categories of proprietary and novelty items these items companies should produce and inhouse. But utility and commodities products firms can outsourced.

\section{Methodology}

In this research we have use questionnaire survey as the primary mode of collection data, it is very important that measures over the instruments of the survey effectively represent the hypothesis under examination. To achieve first this objective, we have completed literature review extensively to find major survey questions. We have also interviewed some company's (already using outsourcing manufacturing) management before going towards finalization stage of the survey questionnaire. The survey's questionnaire sent to the 4,600 manufacturing companies and companies selected randomly from the registered companies list in the USA. So firms varied on the basis on industries, size and City / State. A total of 1904 questionnaire received filled and sent back to us. So ultimately total response rate was $41 \%$ and 134 questionnaire was not filled correctly, so final response rate calculated 38\%. (1770 questionnaire received and filled correctly)

\section{Findings \& Discussion}

After the in-depth analysis of the responses, we were able to represent results, almost $37 \%$ of the companies reported, they have yet to implement to the outsourcing decision for their activities of manufacturing after in-depth reviewing the decisions. And minor involvement reported by $39 \%$. And remaining $24 \%$ companies reported major and extensive involvement with decision of manufacturing outsourcing. Average implies that decision of outsourcing in manufacturing industry are relatively low rate as compare with other industries which represent that's still many manufacturing companies are not willing to use outsourcing manufacturing decisions. $16 \%$ of the respondents told, decision of outsourcing is depend over CEOs, $79 \%$ reported by senior and middle managers. And only $5 \%$ reported that's this decision is made by consultants hired by company. As well in the research results it also identified that's almost $45 \%$ manufacturing outsourcing decision used in batch processing account.

All manufacturing of outsourcing decision, which is related directly from production is $31 \%$, and logistics and warehousing is $45 \%$. in IT is $14 \%$. And only $10 \%$ was reported outsourcing regarding raw material procurement process.

Table 1. Core and Non-Core Manufacturing activities.

\begin{tabular}{|c|c|c|c|c|c|}
\hline \multirow[t]{2}{*}{ Manufacturing Activity } & \multirow[b]{2}{*}{$\%$} & \multicolumn{2}{|c|}{ Non-Core Competency \% } & \multicolumn{2}{|c|}{ Core Competency \% } \\
\hline & & Commodity & Utility & Novelty & Proprietary \\
\hline Raw Material & 7.9 & 41.1 & 20.1 & 32.1 & 6.7 \\
\hline Warehousing \& Inventory Control & 17.5 & 38.2 & 44.6 & 14.4 & 2.8 \\
\hline Manufacturing Activity & 28.1 & 28.1 & 20.4 & 32.1 & 19.4 \\
\hline Quality Control & 2.1 & 49.0 & - & 51.0 & - \\
\hline Distribution \& Logistics & 15.1 & 35.5 & 40.0 & 21.4 & 3.1 \\
\hline
\end{tabular}




\begin{tabular}{|c|c|c|c|c|c|}
\hline \multirow[t]{2}{*}{ Manufacturing Activity } & \multirow[b]{2}{*}{$\%$} & \multicolumn{2}{|c|}{ Non-Core Competency \% } & \multicolumn{2}{|c|}{ Core Competency \% } \\
\hline & & Commodity & Utility & Novelty & Proprietary \\
\hline Research \& Development & 1.9 & 39.1 & 37.9 & 14.9 & 8.1 \\
\hline Product \& Process Engineering & 8.3 & 31.5 & 43.7 & 24.8 & - \\
\hline Information Technology & 13.2 & 29.6 & 47.9 & 22.5 & - \\
\hline Miscellaneous / Other & 5.9 & 53.8 & 37.0 & 9.2 & - \\
\hline$\%$ & 100.0 & 33.2 & 30.8 & 23.3 & 12.7 \\
\hline
\end{tabular}

Table 1 shows the results of the study about core and noncore activities outsourced by companies. If we look over competence of core activities so $12 \%$ of companies has outsourced proprietary, and if we look at novelty activities so almost $22.3 \%$ companies has outsourced their novelty related activities. Production is $28 \%$ share in all outsource manufacturing related activities $(19.4 \%$ for proprietary and $32 \%$ for novelty products). Companies are breaking with the conservative understanding dictating that only non-core activities can be outsourced but now outsourcing activities are increasing in their core areas of business. There is no doubt, still majority activities are outsourcing from noncompetency manufacturing (utility and commodity) related activities which is almost $64 \%$. But from last few decades many companies are also outsourcing their core competencies, the reasons of this changing trend are operating cost (controlling), improving firm focus, access to world class (market) capabilities, and resources make free for other purposes. Following are the benefits derived by Manufacturing Outsourcing Decisions.

Table 2. Benefits Achieve by outsourcing Decision.

\begin{tabular}{lll}
\hline Benefits & Mean & $\begin{array}{l}\text { Standard } \\
\text { Error }\end{array}$ \\
\hline Enhanced Ability to focus over core competencies & 3.22 & 0.15 \\
Improved responsiveness & 3.19 & 0.16 \\
Enhanced Flexibility & 3.18 & 0.14 \\
Financial gains & 3.04 & 0.13 \\
Increased Customer Satisfaction & 2.97 & 0.14 \\
Improved Company focus & 2.94 & 0.14 \\
Strategic Enhancements & 2.75 & 0.15 \\
Shortened Cycle Time & 2.67 & 0.15 \\
Technological improvement of operations & 2.57 & 0.14 \\
Better access to new technology & 2.49 & 0.15 \\
Reduced employee training cost & 2.21 & 0.13 \\
improved management system & 2.18 & 0.14 \\
\hline
\end{tabular}

In this study, we asked from respondents (A5-point likert scale used $5=$ extremely beneficial, $1=$ no beneficial) to assess the major advantages which derived by outsourcing decisions. As per the research results 12 benefits resulting from manufacturing outsourcing decisions. The first is "enhancing the ability to focus on core competencies" because companies doing their many activities outsourced because they want to give more concentration and importance to other strategic issues.

Table 3. Impact on Competitive Capabilities by Outsourcing Decision

\begin{tabular}{lll}
\hline Competitive Capabilities & Mean & Standard Error \\
\hline Deliver Products on time & 2.82 & 0.15 \\
Quick delivery of product & 2.76 & 0.13 \\
Competitive price & 2.47 & 0.14 \\
Consistent Quality & 2.39 & 0.16 \\
\hline
\end{tabular}

\begin{tabular}{lll}
\hline Competitive Capabilities & Mean & Standard Error \\
\hline High performance Products provide & 2.38 & 0.13 \\
Flexibility in terms of changing market & 2.31 & 0.14 \\
demand & & \\
Launched new products in market quickly & 1.93 & 0.15 \\
Increased to the Distribution Networks & 1.87 & 0.13 \\
Provide After sale service & 1.47 & 0.13 \\
\hline
\end{tabular}

In the survey, we asked from respondents to rate (A5point likert scale used $5=$ extremely very important, $1=$ not important) to the "How outsourcing decisions can help to improve competitive capabilities of the firm" the first and most competitive capabilities are "right delivery of product"

In a business in which basic component like processors get to be out of date a several times in a year, OEMs (Original Equipment Manufacturer) are under pressure to expand producing Flexibility, reduction stock (Inventory) prerequisites, and abbreviate (shorten) time to market. Outsourcing manufacturing decisions could permit organizations to meet those objectives and in addition free working capital, which could be diverted to core competency areas of business.

Table 4. Manufacturing outsourcing success affected by following factors.

\begin{tabular}{lll}
\hline Factors of Success & Mean & $\begin{array}{l}\text { Standard } \\
\text { Error }\end{array}$ \\
\hline Supplier Reliability & 4.18 & 0.08 \\
Competence of the supplier & 3.93 & 0.12 \\
Capability of supplier in Manufacturing activities & 3.81 & 0.13 \\
Reducing operating cost & 3.64 & 0.11 \\
Improvement in Customer service & 3.62 & 0.13 \\
Financial Justification (Long Term) & 3.61 & 0.15 \\
Minimizing Manufacturing Cost & 3.57 & 0.14 \\
Utilize resources which are not available internally & 3.55 & 0.14 \\
Customer and Supplier relationships & 3.46 & 0.13 \\
Control on the information of Proprietary & 3.40 & 0.15 \\
Stabilizing Supply & 3.32 & 0.17 \\
Use Internal resources for other purposes & 3.28 & 0.14 \\
Partnering relationship with Supplier (Long Term) & 3.24 & 0.13 \\
\hline
\end{tabular}

Key success factors of the manufacturing outsourcing. And it was the one of the basic aim of this article. The most important factor is the "suppliers' reliability" from the top 13 factors. Which are driving factors of successful manufacturing outsourcing, the success of outsourcing in automobile sector is strategic alliance with the partner (outsourcing). As well other studied also indicate the supplier relationships and management are very important factor in the outsourcing success. And these studied also identified that's "for successful outsourcing agreement long term relationship with supplier are extremely important). Yet many manufacturing companies do not feel comfortable to build long term relationships with supplier because majority 
manufacturing firms has less than 4 years agreement with their suppliers for outsourcing.

\section{Conclusion and Future Research}

When manufacturing outsourcing decision properly implemented, achieving the competitive edge, as per the results of study companies who have adopted outsourcing as a strategic manner, they are better than those companies whose utilizing outsourcing only for cost cutting (short term and tactical decision). Senior management should defined clearly which work they can do in-house (have capabilities and skills) and which they cannot do in a better way, outsourcing can use to make and build internal competency. As well companies should think more about manufacturing outsourcing decision but not only in the perspective of "cost cutting". But in the perspective like increase to the flexibility, decrease to the inventory level and investment, right and quickly delivery. Effective manufacturing outsourcing strategies are not just implemented but should be shaped and mold for particular firm with particular firm competitive needs. Future research can be conducted to analyze more success factors involved in the manufacturing outsourcing decision as well every market have different dynamics and organizational behavior so this research only conducted on in the U. S market. Future researcher can also conducted comparative research in different markets.

\section{References}

[1] Collins, R. S and Bechler, K. A. (1998) Outsourcing of Manufacturing: Learning from the Automobile Industry" $29^{\text {th }}$ annual meeting of the Decision Science Institute, Las Vegas, USA.
[2] Dornier, P., Ernst, P., Fender, M., and Kouvelis, P. (1999) Global Operations and Logistics: Text and Cases. New York: John wiley \& Sons.

[3] Mishina, K (1993). Automotive System Group: The Georgetown, Kentucky Plant, Harvard Business Case \# 693086.

[4] Quinn, J. B., and Hilmer, F. G. (1994) Strategic Outsourcing Sloan Management Review 35, no. 4: 43-55.

[5] Welch, J. A., and Nayak, P. R. (1992) Strategic Sourcing A Progressive Approach to the Make or Buy Decision, Academic of Management Executives 6, no. 1: 23-31.

[6] Mcclintock, K. A. (2002) Global Sourcing for Contract Manufacturing, Case Study - Banner Pharmaceutical Inc.

[7] Elliott, H. (1999) Contract Manufacturing is a Global Game, Electronic news 45, no. 38: 16.

[8] Kotabe, M. (1998) Efficiency vs. Effectiveness Orientation of Global Sourcing Strategy: A Comparison of U. S and Japanese Multinational Companies, Academy of Management Executive 12, no. 4: 107 to 120.

[9] Thuermer, K. E. (2000) Contract Bridges, Export Today's Global Business 16, no. 8: 36 to 41.

[10] Young, P. K. Y. (1998) Determine the Difference between Global, International, Westchester County Business Journal 37, no. 21: 13 .

[11] Guan, J. (2002) Comparison Study of Industrial Innovation between China and Some European Countries, Production and Inventory Management Journal APCIS, US.

[12] Cantoria, C. S. (2014). History of Outsourcing, The notable Timeline History of Outsourcing in America data retrieved from http://www.brighthub.com/office/humanresources/articles/100143.aspx on February 12, 2015.

[13] Narayanan, L. (2010). Brief History of Outsourcing, ABCAmega's Free Client newsletter, data retrieved from http://www.credittoday.net/public/Brief_History_of_Outsourci ng.cfm on February 18, 2015. 